\title{
SYSTEMY ZARZĄDZANIA ENERGIĄ JAKO NARZĘDZIE WSPIERAJĄCE PROCES RACJONALIZACJI ZUŻYCIA ENERGII W ORGANIZACJACH
}

\author{
Aleksandra Koszarek-Cyra \\ Politechnika Częstochowska \\ Wydział Zarządzania
}

\begin{abstract}
Streszczenie: W artykule przedstawiono systemy zarządzania energią jako narzędzie wspierające proces racjonalizacji zużycia energii. W szczególności skupiono się na roli tych systemów na etapie planowania działań proenergetycznych, a także ewaluacji ich skuteczności. Zaprezentowano podstawowe elementy systemów zarządzania energią, a także scharakteryzowano korzyści, jakie mogą wynikać z wprowadzenia takich systemów w organizacjach.
\end{abstract}

Słowa kluczowe: systemy zarządzania energią, SZE, efektywność energetyczna, racjonalizacja zużycia energii

DOI: 10.17512/znpcz.2016.2.18

\section{Wprowadzenie}

Zagadnienia dotyczące zachowania środowiska naturalnego $w$ jak najlepszym stanie, w tym ograniczenia zanieczyszczeń wody, powietrza czy gleby, a także zmniejszenia zużycia zasobów naturalnych, są od dawna podejmowane w dyskusji na poziomie krajowym i międzynarodowym. Szczególną rolę w tych rozważaniach odgrywają problemy związane z wytwarzaniem i użytkowaniem energii.

Nie od dzisiaj wiadomo, że energia jest kluczowym czynnikiem dla współczesnych gospodarek. Już w latach siedemdziesiątych ubiegłego wieku, w wyniku kryzysu paliwowego, rosnących cen energii i raportów mówiących o wyczerpywalności surowców energetycznych, dostrzeżono konieczność zarząadzania zużyciem energii. Mimo podejmowanych działań w zakresie zmniejszenia energochłonności zapotrzebowanie na energię ciągle rośnie (Rysunek 1).

Obecnie zakłada się, że oszczędzona (nieużyta) energia jest najczystszą, pozbawioną negatywnych skutków ekologicznych metodą obniżenia emisji szkodliwych substancji, a poprawa efektywności energetycznej jest najbardziej opłacalnym sposobem zmniejszenia kosztów zużycia energii. Inwestycje wpływające na racjonalizację zużycia energii mogą powodować pozytywne skutki zarówno na poziomie pojedynczej organizacji, gwarantując jej obniżenie kosztów i poprawę wizerunku firmy, ale również stosowane w szerszej skali, mogą mieć znaczenie na poziomie krajowym, przyczyniając się do wzrostu konkurencyjności gospodarki danego państwa na rynku światowym (Kucęba, Koszarek-Cyra, 2015). 


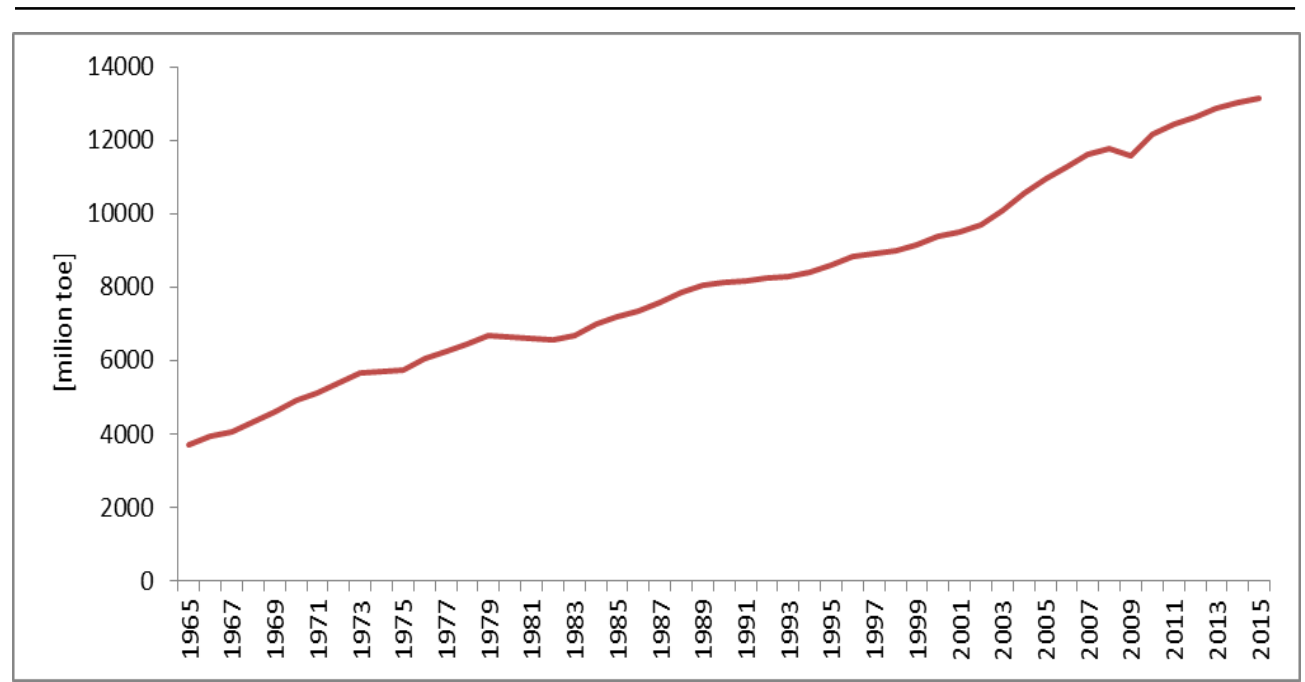

\section{Rysunek 1. Światowe zużycie energii w latach 1965-2015}

Źródło: Opracowania własne na podstawie danych statystycznych publikowanych przez BP (http://www.bp.com/en/global/corporate/energy-economics/statistical-review-of-worldenergy.html)

Mimo że w ciągu ostatnich kilkunastu lat nastąpiła znaczna poprawa w zakresie wykorzystania energii w Polsce, a tempo poprawy energochłonności według danych GUS (GUS 2015) było w Polsce w latach 2000-2011 ponad dwukrotnie wyższe niż w Unii Europejskiej, to efektywność energetyczna gospodarki Polski jest nadal dwukrotnie niższa w porównaniu z krajami tzw. starej Unii. Konieczne są zatem dalsze działania w kierunku poprawy energoefektywności.

Niemniej jednak należy zaznaczyć, że presja w kierunku optymalizacji zużycia energii i zwiększania efektywności energetycznej wywierana na przedsiębiorstwa przez społeczeństwo, organizacje pozarządowe, ale także uwarunkowana prawnie przez dyrektywy unijne czy prawodawstwo krajowe, spowodowała zmianę w sposobie zarządzania energią w przedsiębiorstwach i włączenie tego aspektu do ogólnego systemu zarządzania organizacjami.

Obecnie coraz częściej przedsiębiorcy podejmują różnego typu działania prośrodowiskowe, $\mathrm{w}$ tym te związane $\mathrm{z}$ racjonalizacją zużycia energii i ograniczeniem konsumpcji surowców. Ich celem, z punktu widzenia przedsiębiorcy, jest przede wszystkim ograniczenie kosztów energii bez konieczności zmniejszania produkcji czy jakości usług (Abdelaziz, Saidur, Mekhilef 2011), ale również aktywności tego typu mogą być elementem PR-owym, pozwalającym budować pozytywny wizerunek organizacji.

Narzędziami wspierającymi proces racjonalizacji zużycia energii mogą być systemy zarządzania energią (SZE, ang. Energy Management System - EnMS), jednak mimo niewątpliwych korzyści wynikających z ich implementacji do systemu zarządzania przedsiębiorstwem nadal wiele firm ich nie wdrożyło (Dörr, Wahren, Bauernhansl 2013). 


\section{Zarządzanie energią w przedsiębiorstwie}

Zarządzanie energią, czy raczej zużyciem energii, bywa różnie definiowane w literaturze. Mówi się o nim np. jako o systematycznym stosowaniu zarządzania i technologii do polepszenia charakterystyki energetycznej (ISO 50001: Energy Management System. Carbon Trust. Energy Management - A Comprehensive Guide to Controlling Energy Use, 2011), jako o kontroli, monitoringu i prowadzeniu działań zwiększających energoefektywność (Bunse i in. 2011) czy jako o doskonaleniu efektywności energetycznej organizacji poprzez wprowadzanie szeregu środków i metod mających na celu ułatwienie realizacji zadań proenergetycznych, dzięki któremu można zapewnić organizacji nieprzerwane dostawy energii i obniżenie kosztów jej zużycia (Javied, Rackow, Franke 2015).

Niezależnie jednak od przyjętej definicji można założyć, że głównymi przyczynami podejmowania działań związanych $\mathrm{z}$ zarządzaniem zużyciem energii i surowców energetycznych są:

1. chęć zwiększenia energoefektywności, a co za tym idzie - obniżenia kosztów działalności;

2. przestrzeganie przepisów prawa związanych z racjonalizacją zużycia energii;

3. sprostanie standardom wymaganym przez klientów.

W celu uproszczenia realizacji powyższych potrzeb coraz częściej implementowane są $\mathrm{w}$ organizacjach systemy zarządzania środowiskowego, w tym systemy zarządzania energią.

Systemy zarządzania energią mogą mieć charakter znormalizowany, np. mogą być oparte o normę ISO 50001 (w Polsce przyjętej jako PN-EN 500001:2012. Systemy zarządzania energia - wymagania i zalecenia użytkowania) lub też mogą być systemami dedykowanymi stworzonymi dla konkretnej organizacji (np. Programy typu Energiaa 4 stworzone przez częstochowską firmę NUMERON).

Niezależnie od typu przedsiębiorstwa i branży, w której ono funkcjonuje, system zarządzania energią powinien zawierać:

- politykę (strategię) energetyczną firmy wraz z celami strategicznymi i operacyjnymi;

- opis sytuacji wyjściowej wraz z analizą danych historycznych - często obejmujący raport $\mathrm{z}$ audytu energetycznego;

- opis procedur, środków i metod wprowadzenia optymalizacji;

- schemat struktury organizacyjnej wraz z obowiązkami personelu związanego $\mathrm{z}$ wprowadzaniem zmian;

- opis systemu szkoleń, prowadzenia dokumentacji, komunikacji wewnątrz organizacji i sposobu raportowania wyników (Abdelaziz, Saidur, Mekhilef 2011; Weidong i in. 2011; ISO 50001: Energy Management System).

\section{Etapy wdrożenia systemu}

Pierwszym etapem wdrażania systemu zarządzania energią $\mathrm{w}$ przedsiębiorstwie jest stworzenie zespołu pracowniczego, który będzie planował, koordynował i kontrolował działania. Ważne jest, by zespół taki był interdyscyplinarny, repre- 
zentowany przez osoby z różnych działów przedsiębiorstwa, jak również z różnych poziomów organizacji, od czołowego kierownictwa, po dział, który będzie realizował cele operacyjne. Dzięki temu można zaplanować działania, które będą realne do wykonania w danej organizacji.

Kolejnym krokiem jest analiza bieżącego stanu przedsiębiorstwa i stworzenie polityki energetycznej wraz z celami strategicznymi, jakie organizacja chciałaby osiągnąć przez wprowadzenie zmian. Pomocnymi narzędziami na tym etapie mogą być audyty energetyczne i audyty efektywności energetycznej. Mogą one ułatwić określenie wariantów możliwych w przyszłości działan i wybór najbardziej optymalnych.

Po określeniu celów strategicznych, operacyjnych i obraniu kierunków działania należy opracować dokładny plan wdrożenia optymalizacji, łącznie z harmonogramem prac, strukturą organizacyjną, personalną, a także sposobem obiegu informacji, monitorowania i kontroli prowadzonych działań.

Po fazie planowania następuje etap implementacji SZE. Podczas tej fazy należy przeprowadzić szkolenia pracowników, rozdzielić zadania, wdrożyć optymalizację, zadbać o dokładne dokumentowanie prowadzonych procesów i bieżące raportowanie zmian.

Po zakończeniu stadium wdrożenia należy przeprowadzić kontrolę wyników optymalizacji; może mieć ona postać ponownego audytu.

Etapem końcowym jest analiza efektywności prowadzonych działań i zaplanowanie kolejnych optymalizacji.

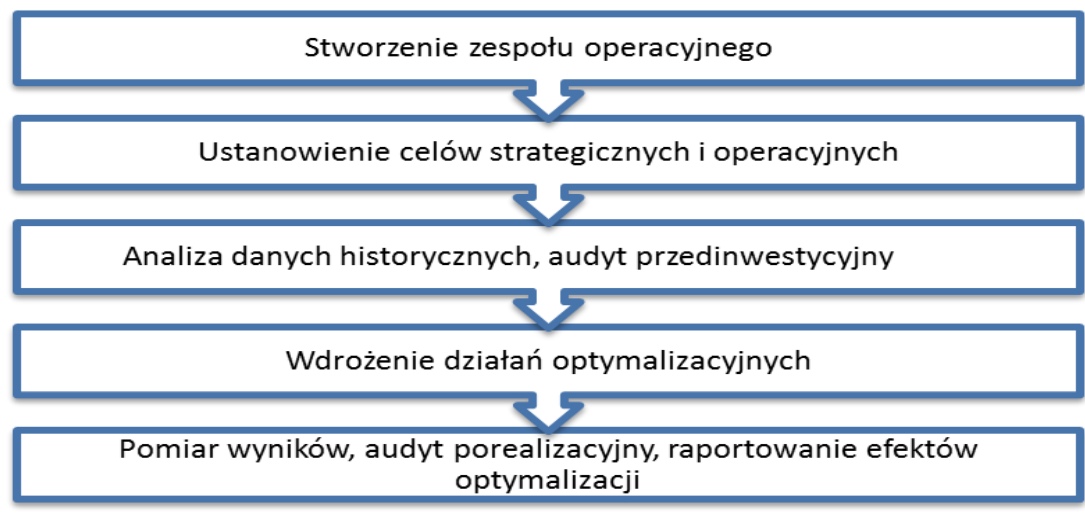

\section{Rysunek 1. Etapy wprowadzania systemu zarządzania energią}

Źródło: Opracowanie własne na podstawie (Saidur 2010)

\section{ISO 50001}

Do najbardziej popularnych systemów zarządzania energią należą te oparte na ISO 50001. Mogą być one stosowane we wszystkich typach i rozmiarach organizacji, bez względu na branże czy uwarunkowania geograficzno-społeczne, a oszczędność energii dzięki ich zastosowaniu według danych szacunkowych może sięgać nawet do kilkudziesięciu procent (Stoma, Dudziak, Piekarski 2014). 
Norma IS0 50001 zastąpiła wcześniej obowiązującą normę ISO 16001:2009, która skupiała się głównie na dostosowaniu aspektów energetycznych do kwestii ochrony środowiska; nowa norma kładzie nacisk przede wszystkim na racjonalizację zużycia energii.

Działania w normie 50001, podobnie jak w innych systemach ISO, oparte są na tzw. cyklu Deminga - strukturze PDCA (Plan-Do-Check-Act), która zakłada ciągłe udoskonalanie sytemu i wprowadzanie coraz to nowych optymalizacji.

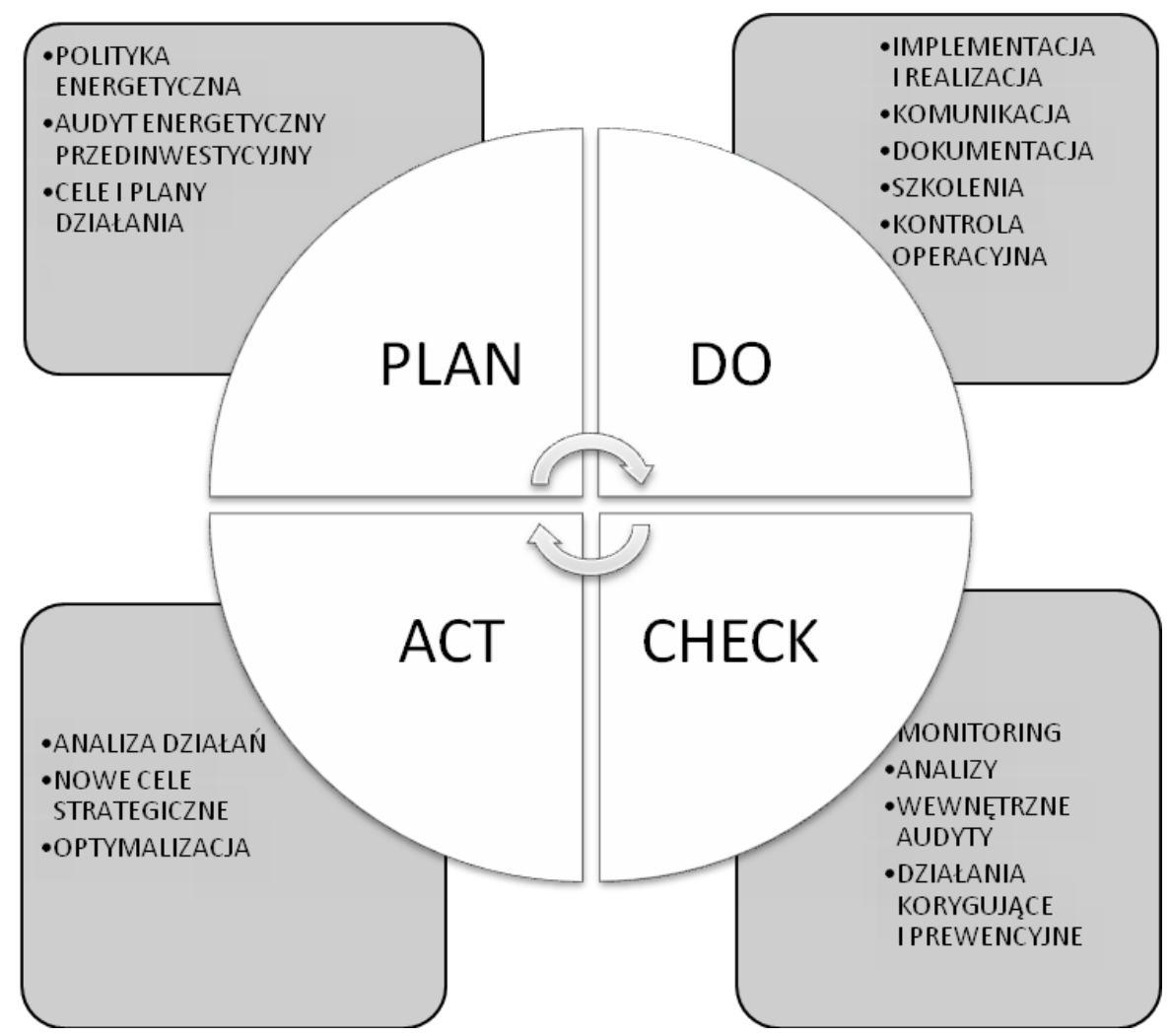

Rysunek 2. Struktura SZE ISO 50001 - cykl PDCA

Źródło: Opracowanie własne na podstawie: (http://www.cleanenergyministerial.org/OurWork/Initiatives/Energy-Management/Energy-Management-ISO-50001)

Mimo tego, że systemy oparte na normie ISO 50001 są jednymi z najbardziej popularnych, to liczba wdrożeń w przedsiębiorstwach nie jest imponująca. Z danych opublikowanych na stronie International Organization for Standardization (http://www.iso.org/iso/home/standards/certification/isosurvey.htm?certificate=ISO $\% 2$ 050001\&countrycode=PL\#standardpick) wynika, że mimo iż liczba implementacji ISO 50001 rokrocznie wzrasta, nadal liczba wdrażanych systemów jest niewielka rocznie kilka tysięcy takich systemów na całym świecie (w 2014 roku - 6778). 


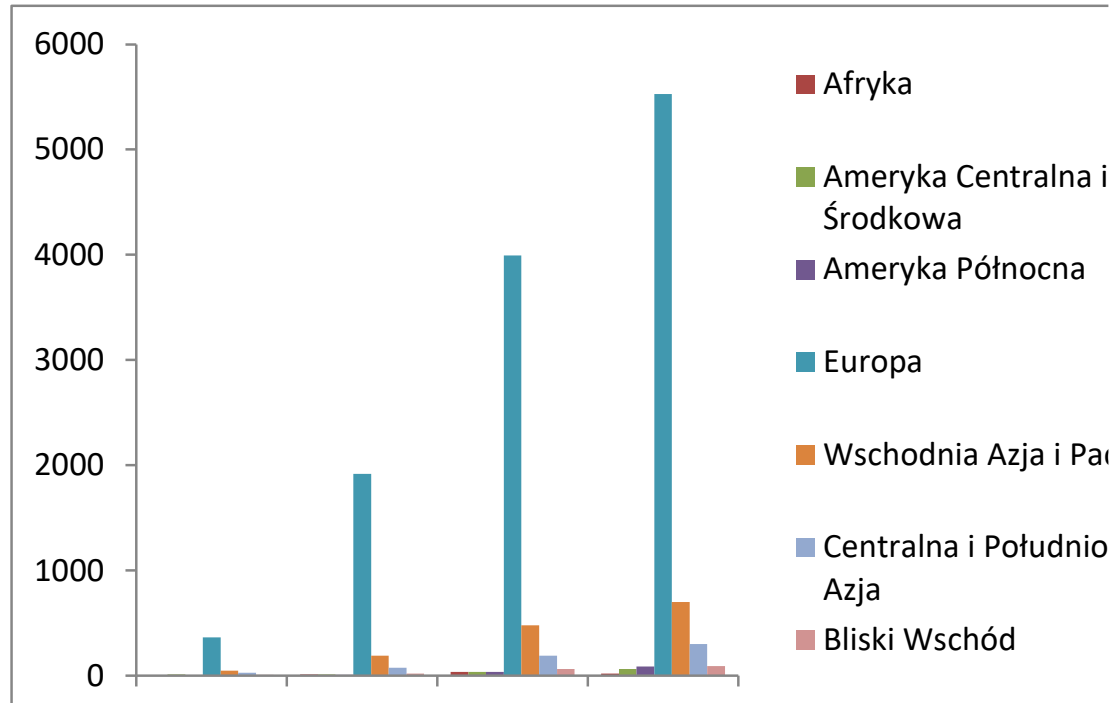

Rysunek 3. Liczba wdrożeń systemów opartych na IS0 50001

Źródło: Opracowanie własne na podstawie danych International Organization for Standardization

W Polsce liczba firm z wdrożoną normą IS0 50001 jest bardzo mała - 74 wdrożenia w okresie 4 lat - 2011-2014.

Dla porównania norma środowiskowa ISO $14001 \mathrm{w}$ samej Europie wdrożona była 123849 razy w roku 2014 (w Polsce 2213 wdrożeń). Jest ona, jak widać, o wiele chętniej wdrażana przez przedsiębiorców, co może wynikać zarówno z jej większej uniwersalności, ale również z dłuższej obecności na rynku.

\section{Korzyści płynące $\mathrm{z}$ wdrożenia systemów zarządzania energią}

Niski wskaźnik wdrożeń systemów zarządzania energią jest zaskakujący, biorąc pod uwagę korzyści, jakie przedsiębiorstwo może uzyskać, wprowadzając taki element do ogólnej struktury zarządzania.

Poza oczywistymi benefitami wynikającymi z implementacji SZE, jakimi są redukcja zużycia energii, a co za tym idzie - obniżenie kosztów działalności bieżącej przedsiębiorstwa i zmniejszenie negatywnego wpływu organizacji na środowisko naturalne, poprzez m.in. redukcję emisji gazów cieplarnianych; niezwykle ważna dla organizacji może być możliwość budowania jej pozytywnego wizerunku. Firma dbająca o środowisko $\mathrm{w}$ dzisiejszych czasach postrzegana jest jako przedsiębiorstwo nowoczesne i dobrze zarządzane. Dlatego też działania prośrodowiskowe mogą być szansą na zwiększenie konkurencyjności na rynku i ułatwienie pozyskiwania nowych klientów, szczególnie wśród grupy kontrahentów „ekologicznie wrażliwych".

Przedsiębiorstwo wdrażające systemy zarządzania energią może odnieść również wiele innych, pośrednich korzyści wynikających z usprawnienia swojej działalności. Będą one zależne od rodzaju wprowadzonych działań i specyfiki przed- 
siębiorstwa. Przykładowo: usprawnienie kontroli działań produkcyjnych może skutkować wzrostem ich wydajności i stabilności, działania związane $\mathrm{z}$ termomodernizacją nieruchomości mogą zaowocować zwiększeniem komfortu użytkowania budynków, a tym samym lepszymi warunkami pracy, częstsze okresowe przeglądy maszyn mogą przyczynić się do zmniejszenia przestojów i awarii, a same prace związane $\mathrm{z}$ implementacją SZE mogą poprawić pracę zespołową i skutkować zwiększeniem świadomości ekologicznej pracowników (ISO 50001: Energy Management Systems - A Practical Guide for SMEs).

W szerszej perspektywie działania proekologiczne przedsiębiorstw przyczyniaja się do realizacji zobowiązań w zakresie polityki klimatyczno-energetycznej Unii Europejskiej i są formą implementacji idei zrównoważonego rozwoju.

\section{Podsumowanie}

Mimo że nadal niewielki odsetek organizacji wdraża u siebie systemy zarządzania energią, nie ulega wątpliwości, że działania prośrodowiskowe coraz częściej realizowane są w polskich przedsiębiorstwach. Sektor biznesu takie aktywności powoli zaczyna traktować nie tylko jak koszty wynikające z mody na „działania ekologiczne", ale przede wszystkim jako inwestycje, które mogą przynieść wymierne korzyści w przyszłości, dlatego można założyć, że w dalszej perspektywie zarządzanie środowiskowe, a w tym zarządzanie energią, będzie nieodłącznym elementem zarządzania każdą organizacją, a systemy zarządzania energią staną się obowiązującym standardem.

\section{Literatura}

1. Abdelaziz E., Saidur R., Mekhilef S. (2011), A Review on Energy Saving Strategies in Industrial Sector, "Renewable and Sustainable Energy Reviews", Vol. 15, s. 150-168.

2. Bunse K., Vodicka M., Schönsleben P., Brülhart M., Ernst F.O. (2011), Integrating Energy Efficiency Performance in Production Management - Gap Analysis between Industrial Needs and Scientific Literature, "Journal of Cleaner Production”, Vol. 19(6-7), s. 667-679.

3. Dörr M., Wahren S., Bauernhansl T. (2013), Methodology for Energy Efficiency on Process Level, "Procedia CIRP", Vol. 7, s. 652-657.

4. GUS (2015), Efektywność wykorzystywania energii w latach 2003-2013, Warszawa.

5. http://www.bp.com/en/global/corporate/energy-economics/statistical-review-of-worldenergy.html (dostęp: 17.04.2016).

6. http://www.cleanenergyministerial.org/Our-Work/Initiatives/Energy-Management/EnergyManagement-ISO-50001 (dostęp: 17.04.2016).

7. http://www.iso.org/iso/home/standards/certification/isosurvey.htm?certificate=ISO $\% 205000$ 1\&countrycode=PL\#standardpick (dostęp 20.12.2015).

8. ISO 50001: Energy Management System.

9. ISO 50001: Energy Management System. Carbon Trust. Energy Management - A Comprehensive Guide to Controlling Energy Use, 2011.

10. ISO 50001: Energy Management Systems - A Practical Guide for SMEs, Genewa 2015, http://www.iso.org/iso/50001_handbook_preview.pdf (dostęp: 17.04.2016).

11. Javied T., Rackow T., Franke J. (2015), Implementing Energy Management System to Increase Energy Efficiency in Manufacturing Companies, "Procedia CIRP”, Vol. 26, s. 156-161. 
12. Saidur R. (2010), A Review on Electrical Motors Energy Use and Energy Savings, „Renewable and Sustainable Energy Reviews", Vol. 14, s. 877-898.

13. Kucęba R., Koszarek-Cyra A.,(2015) Kierunki, bariery, determinanty zarzadzania energia w organizacjach MSP. W: Zeszyty Naukowe Politechniki Śląskiej, seria: Organizacja i Zarządzanie z. 83. S. 375-384.

14. Stoma M., Dudziak A., Piekarski W. (2014), Systemy zarządzania energia narzędziem zarzadzania organizacja i jej zasobami energetycznymi. Materiały pokonferencyjne Konferencji Innowacje w Zarzadzaniu i Inżynierii Produkcji. Rok 2014, http://www.ptzp.org.pl/ files/konferencje/ kzz/artyk_pdf_2014/T1/t1_357.pdf (dostęp: 14.04.2016).

15. Weidong F., Wei H., Kunya W., Huoyin L., Zhihao J. (2011), A Method to Establish and a Run Management System for Energy, "Energy Procedia”, Vol. 5, s. 1584-1588.

\title{
ENERGY MANAGEMENT SYSTEMS AS A SUPPORTING TOOL FOR THE PROCESS OF INCREASING ENERGY EFFICIENCY IN ORGANISATIONS
}

\begin{abstract}
The article presents energy management systems as a supporting tool for the process of energy consumption rationalization. In particular it focuses on the role of these systems in the planning stage of energy efficiency activities, and the evaluation of their effectiveness. It presents the basic elements of energy management systems, and characterized the benefits that may result from the introduction of EnMS in organizations.
\end{abstract}

Keywords: energy management systems, EnMS, energy efficiency 